DOI https://doi.org/10.18551/rjoas.2018-08.22

\title{
EFFECT OF ACCOUNTING INFORMATION SYSTEM FOR INTERNAL CONTROL «SIPPUH ONLINE» IN PT. DWIMAJAYA UTAMA
}

\author{
Pravitasari Nirwana Putri \\ Airlangga University, Indonesia \\ E-mail: nirwanapvita@gmail.com
}

\begin{abstract}
This study aims to determine the effect of the application of accounting information systemSIPPUH Online on internal control inventory PT Dwimajaya Utama. The sample used in this study is the staff of the timber business and accounting staff as much as 34 respondents. Data analysis technique used regression. The results showed there are significant application of the effects of the application of accounting information system-SIPPUH Online on internal control inventory PT Dwimajaya Utama.
\end{abstract}

\section{KEY WORDS}

Accounting, information, systems, inventories.

The role of accounting in the business world to be one thing that is taken into account at the moment, business development increasingly fast was also accompanied by the development of an advanced accounting knowledge applied in the business world. Economic development faster and faster pushing the company to improve its performance in order to survive and thrive. The objective of establishing a company to continue to operate and generate profits sufficient for the survival of the company. Before going into the process of production and sales to be considered is the supply of goods. The present study discusses the application of SIPPUH Online in inventory systems at PT Dwimajaya Utama, the company is moving dbidang forestry and forest management activities by IUPHHKHA PT Dwimajaya Utama namely selective cropping Indonesia (TPTI). Where in the process of recording supplies the Ministry of environment and forestry publish Candy LHK No. P.43 / Menlhk-Secretariat / 2015 dated December 12, 2015, since the enactment of the regulations then the whole company engaged in forestry and hutanwajib to use SIPUHH (Business Licensing Information System Forest Products) ONLINE in the administration and publication of various documents wood,

The use SIPUHH Online is expected to help in controlling inetrnal related companies recording inventories, of the system can be monitored how the movement of supplies, in addition to facilitate the company to record inventory logs, these implementations also memebantu the ministry to monitor the circulation of wood for each company. So things that are illegal, mistakes will meneyebabkan company's losses can be avoided.

\section{LITERATURE REVIEW}

Accounting information system. According Niswonger, Fess \& Warren (1995), accounting information system is an internal tool used by companies to obtain information that the information will be used as consideration for managing the company's financial reports and related presentation for stakeholders.Accounting Information Systems (AIS) is a part of a company that works to collect, clarify, process, analyze, and communicate information as a consideration of decision-making that decision is useful for internal and external parties companies (Moscove and Simkin, 1984; in Jogiyanto 2007: 17).

Online Sipuhh. Refer to Regulation of the Minister of Environment and Forestry of the Republic of Indonesia Number: P.43 / Menlhk-Secretariat / 2015 Concerning Administration of Timber Forest Products Derived From Natural Forests, a company engaged in forestry and forest management are required to use the Online Sipuhh issued by the Ministry of the Environment and Forestry of the Republic of Indonesia. The meaning of forest governance 
timber forest products derived natural forests are intended to guarantee the rights of the state over all forest products timber from natural forests exploited and / or cut and / or collected by the permission / management rights in accordance with the provisions of the law -invitation. Tata forest management from natural forests aimed at ensuring legality and order circulation timber forest products as well as the availability of data and information. The scope includes the entire timber forest products are derived from natural forests exploited or felled by pengelolahutan / holder of a valid license and implemented self assessment through SIPUHH. The whole company engaged in forestry and forest management are required to make Production Report which must then be uploaded via Online SIPUHH application.

Inventories. According C.Rollin Niswonger, Philip E. Fess, and \& Carl S.Warren (1995) interpret the definition of inventory (inventory) is used to denote items stored merchandise to be sold in the normal operation of the company, and that the material in the production process or saved for that purpose. Interest Inventory Accounting Information Systems:

- Provide accurate information related to admission to the receipt of inventory in accordance with the procedures adopted by the company;

- Provide information about the flow of existing inventory so that local governments can take into account the degree of control required;

- Inventory control so that supplies can be calculated economically existence.

Internal Control Systems. According to Mulyadi, 2008 states that the internal control system includes organizational structure, methods, measures that are coordinated to maintain the wealth of the organization, check the accuracy and reliability of accounting data, drive efficiency and encourage compliance with management policies. Meanwhile, according to the definition of internal control according to Amin Widjaja Tunggal (2010) mendefinikan system of internal control is a process that is run by the Board of Commissioners, Management, Personal other entities that are designed to provide reasonable assurance about the achievement of the three factions of the following purposes: (a) the reliability of financial reporting (b) Effectiveness and efficiency of operations, and (c) Compliance with laws and regulations.

\section{RESEARCH HYPOTHESES}

Effect of Accounting Information System implementation of the internal control inventory. Based on research conducted by Djajun Djuhara (2014) states that there are effects of the application of the accounting information system of internal control of inventory. control.

$\mathrm{H} 1$ : There Effect of Accounting Information System Implementation of the internal

\section{METHODS OF RESEARCH}

Population and Sample Research. The population used in this study is karyawana working at PT Dwimajaya Utama in Palangkaraya. The sampling technique in this research use traditional methods of purposive sampling. The method is based on the criteria for determining the sample used in this study dalah as follows:

- Respondents in this penelitoan are active employees of PT Dwimajaya Utama;

- Respondents are administrative staff and financial staff wooden PT Dwimajaya Utama;

- Respondents are not restricted by long tenure. Dependent variables:

Internal Control Inventory. Inventory in a company is an important asset, because almost all of the biggest expenditures are used for supplies. If the company does not record the entry and exit groove and appropriately then the company can lose money. This inventory account will be associated with third parties, loss can occur when the company experienced delays in product shipments, nonconformity records with physical evidence, if using improper methods, there will be damage to the inventory. Then that is where the role of 
an accounting system in regulating the inventory account. Interest Inventory Accounting Information Systems: (1) Provide accurate information related to admission to the receipt of inventory in accordance with the procedures adopted by the company. (2) Provide information about the flow of existing inventory so that local governments can take into account the degree of control required. (3) Control of supply so that supplies can be calculated economically existence.

Independent variables:

Accounting information system. The accounting information system is a set of financial and non-financial processes that complement each other to produce a useful information to a company official. Indicators used in varaibel accounting information system is the hardware, software, human resources, procedures applied, the company's database, and the communication network.

Hypothesis testing. Model hypothesis test used in this study is a simple linear regression by using SPSS 20 . The independent variables to be tested, namely Information accounting system, while the dependent variable used is the internal control of inventory logs. Thus developed the regression equation as follows:

$$
P I=a+b 1 . S I A+e
$$

Where: $\mathrm{PI}=$ Internal Control; $\mathrm{a}=$ constant; $\mathrm{b}=$ Coefficient independent varaibel (regression coefficient); SIA = Accounting Information Systems; E = Error.

\section{RESULTS AND DISCUSSION}

Test Correlations. To test whether there is influence of variable $X$ to $Y$ varaibel the first step in this research is the correlation test using SPSS 20.0 software for Windows.

Table 1 - Validity Analysis Results

\begin{tabular}{|c|c|c|c|}
\hline Item Questions & Pearson Correlation & significant & Information \\
\hline SIA_1 & $0.473^{* *}$ & 0,005 & VALID \\
\hline SIA-2 & 0.778 ** & 0,000 & VALID \\
\hline SIA_3 & 0.783 ** & 0,000 & VALID \\
\hline SIA_ 4 & 0.663 ** & 0,000 & VALID \\
\hline SIA_5 & $0.713^{* *}$ & 0,000 & VALID \\
\hline SIA_6 & 0.612 ** & 0,000 & VALID \\
\hline SIA_7 & 0.623 ** & 0,000 & VALID \\
\hline SIA_8 & $0.575 * *$ & 0,000 & VALID \\
\hline SIA_9 & 0.649 ** & 0,000 & VALID \\
\hline SIA_-10 & 0.780 ** & 0,000 & VALID \\
\hline SIA_11 & 0.582 ** & 0,000 & VALID \\
\hline SIA_12 & 0,400 ** & 0,019 & VALID \\
\hline SIA_13 & $0,795 * *$ & 0,000 & VALID \\
\hline SIA_14 & 0.572 ** & 0,000 & VALID \\
\hline Pl_1 & 0.658 ** & 0,000 & VALID \\
\hline PI_2 & $0.508^{* *}$ & 0,002 & VALID \\
\hline PI_3 & 0,495 ** & 0,003 & VALID \\
\hline $\mathrm{Pl} 44$ & $0.704^{* *}$ & 0,000 & VALID \\
\hline PI_6 & 0.465 ** & 0,006 & VALID \\
\hline $\mathrm{Pl} 77$ & 0.588 ** & 0,000 & VALID \\
\hline PI_8 & 0.552 ** & 0,000 & VALID \\
\hline PI_9 & $0.563^{* *}$ & 0,001 & VALID \\
\hline PI_10 & 0.626 ** & 0,000 & VALID \\
\hline PI_11 & 0.660 ** & 0,000 & VALID \\
\hline PI_12 & 0.448 ** & 0,000 & VALID \\
\hline PI_13 & 0.450 ** & 0,000 & VALID \\
\hline PI_14 & $0.582^{* *}$ & 0,000 & VALID \\
\hline
\end{tabular}

Sources: Primary data are processed (SPSS output). 
Table 1 shows that the variable of Accounting Information Systems has a valid criterion in any statement items with significant value below 0.05 . This suggests that the terms of validity of the measuring instrument are met and means that all the items of the statements used in this study could reveal something that was measured in the questionnaire.

Test Reliable. To test whether the data obtained from the questionnaire is reliable data, then after further correlation test test is reliable, the following are the results and their interpretation:

Table 2 - Reliable Test Results

\begin{tabular}{ll}
\hline Cronbach's Alpha & $\mathrm{N}$ of Items \\
0.826 & 13 \\
\hline
\end{tabular}

Sources: Primary data are processed (SPSS output).

Based on the above table, Alpha value of $0.826>0.60$, it can be said that the questionnaire is reliable.

Test Regression. Simple linear regression analysis is a regression method that can be used as a tool of statistical inference to determine the effect of avariablefree (independent) on the dependent variable (dependent). Here is a regression test results:

Table 3 - Descriptive Statistics Table

\begin{tabular}{llll}
\hline & mean & Std. deviation & $\mathrm{N}$ \\
\hline PI_RATA2 & 4.2024 & 0.30587 & 34 \\
SIA_RATA2 & 4.1512 & 0.43771 & 34 \\
\hline
\end{tabular}

Sources: Primary data are processed (SPSS output).

Descriptive statistics in the table above, the mean value for Internal Control (PI_RATA2) and Accounting Information Systems (SIA_RATA2) each by 4.2024 and 4.1512 . the standard deviation value for Internal Control (PI_RATA2) and Accounting Information Systems (SIA_RATA2) respectively 0.30587 and $0.43 \overline{77} 1$.

Table 4 - Test Results Analysis The coefficient of determination (Adjusted R2)

\begin{tabular}{lllll}
\hline Model & $\mathrm{R}$ & $\mathrm{R}$ Square & Adjusted R Square & Std. Error of the Estimate \\
\hline 1 & $0,622 \mathrm{a}$ & .387 & 0.368 & 0.24319 \\
\hline
\end{tabular}

Sources: Primary data are processed (SPSS output).

In Table 4 displays the value of $R$ which is a symbol of the value of the correlation coefficient. Correlation coefficient of 0.622 means that the independent variable Accounting Information Systems (AIS) has the effect of a contribution of $38.7 \%$ to the Internal Control variables and $61.3 \%$ are influenced by other factors outside the independent variable of Accounting Information Systems (AIS).

Table 5 - The results of F-test analysis

ANOVAa

\begin{tabular}{llllll}
\hline Model & Sum of Squares & df & mean Square & F & Sig. \\
\hline Regression & 1,195 & 1 & 1,195 & 20.203 & $0,000 \mathrm{~b}$ \\
residual & 1.893 & 32 & 0.059 & & \\
$\quad$ Total & 3,087 & 33 & & & \\
\hline
\end{tabular}

Sources: Primary data are processed (SPSS output).

From table 5 obtained significance probability value of $0.000<0.05$, significant difference effect of accounting information system of internal control.

Test Results Multicollinearity. Here is the result of a test multicollinearity: 
Table 6 - Results Test Analysis Multicollinearity

\begin{tabular}{lll} 
& \multicolumn{3}{c}{ collinearity Statistics } \\
\hline & tolerance & VIF \\
\hline SIA_RATA2 & 1,000 & 1,000 \\
\hline
\end{tabular}

Sources: Primary data are processed (SPSS output).

From table 6 obtained value and the value of tolerance 1 Inflantion Variance Factor (VIF) under the number 10 (ie: 1000) this means there is no regression model multikol problem and can be used in this study.

Normality Test Results. Normality test can be seen from the dissemination of data that follow the normal line as can be seen in Figure 1:

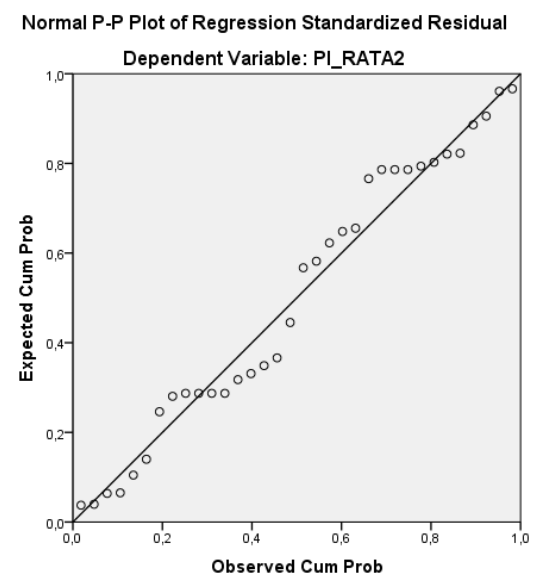

Figure 1 - Normality Test Results

Plot graphic display Normal Regression Standardized PI_RATA2 seen that the points spread around the diagonal line, so that it can be concluded that the data has been collected and processed by investigators fit for use, although some plots were slightly deviates from the diagonal line.

\section{CONCLUSION}

In the discussion has been explained that there is significant influence independent varaibel Accounting Information System on Internal Control Inventory logs on Dwimajaya Utama PT. After doing research, then there are some suggestions for future research such as: socialization of the user regarding Online SIPUHH either use, or how to anticipate machine error system further improved in order to avoid mistakes in the future; for further research please add other variables that may memepengaruhi internal control inventory.

\section{REFERENCES}

1. Amin Widjaja Tunggal.2010. Key Concepts in Auditing and Assurance Service. Jakarta: Harvarindo. IFRS. Jakarta: Index. James Hall (2011).

2. C. Rollin Niswonger, Philip E. Fees, Carl S Warren. 1995. Accounting Principles Volume 1, Ed: 16. Publisher, Jakarta.

3. Djuhara, Djajun and Januariska. 2014. Effect of Accounting Information System on Internal Control Inventory Inventory CV. Tri Manunggal Multi Bandung. Journal of Economics, Business, and Entrepreneurship Vol. 8, No. 2, October 2014. 111-122.

4. Jogiyanto, HM, 2007, Analysis and Design of Information Systems: Theory and Practice Structured Approach Business Applications, Yogyakarta: Andi Offset.

5. Moscove, Stephen A.1984. Accounting information systems: concepts and practice for effection decision making. New York: John Wiley.

6. Mulyadi. 2008. Accounting System. Third Edition, Fourth Printing, Salemba Four, Jakarta. 